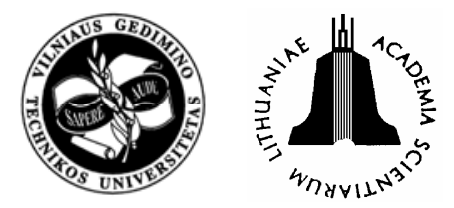

\title{
POSSIBILITIES OF CEMENT CONTENT REDUCTION IN CONCRETES WITH ADMIXTURE OF SUPERPLASTICISER SNF
}

\author{
Aleksander Kapelko \\ Institute of Building Engineering at Wroctaw University of Technology, \\ Pl. Grunwaldzki 11, 50-377 Wroctaw, Poland \\ E-mail: aleksander.kapelko@pwr.wroc.pl
}

Received 06 June 2005; accepted 02 Sept 2005

\begin{abstract}
The problem of the possibility of cement saving in concretes with admixture of sodium salt of formaldehydic polycondensates of sulphonic-napthalene acids (SNF) is presented. Executed investigations show a strong plastifying performance of this admixture as well as an elongation of setting time of Portland cements. On adding 1,5\% of admixture it is possible to obtain a substantial saving of cement with simultaneous reduction of water amount (constant $W / C$ ratio), without a change of consistency of concrete mixture apparent density, compressive strength, absorption and water penetration of concrete. For the estimation of economic effectiveness of superplasticiser SNF it is proposed to introduce an index of cement saving $S_{c}$ and an index of cement utilisation in concretes $I_{e c}$.
\end{abstract}

Keywords: concrete mixture, properties of concrete mixture, superplasticiser SNF, concrete, physical and mechanical properties of concrete, saving of cement, index $S_{c}$ and $I_{e c}$.

\section{Introduction}

The basic functions of plasticising and high-range water reducing admixtures used in cement materials are following [1-5]:

a) the reduction of $W / C$ ratio while maintaining the initial consistency of concrete mixture constant,

b) the reduction of cement and water content without worsening the fluidity of concrete mixture and while sustaining the same value of compressive strength as for the control concrete,

c) the change of concrete mixture consistency into more fluid while maintaining $W / C$ ratio constant (no changes in basic content of concrete mixture).

The cement content in concrete is reduced with regard to two aspects [1-6]:

1. economical-the cost of cement and the possibility of its usage in a smaller quantity,

2. technical - the danger of too big cement shrinkage occurrence.

The main effects of superplasticisers performance: the dispersion of cement granules and plasticising effect associated with this phenomena, the adsorption on the surface of cement granules, causing their repulsion, the increase in shear resistance and the stabilization of paste through electrostatic repulsion, were outlined $[1-4,7]$.

Characteristics of superplasticisers performance are still a subject of ongoing investigations with respect to their adsorption to cement particles [8], the porosity of paste [9], the changes of zeta potential [10] and the compatibility with different cements $[11,12]$.

The changes of concrete mixtures fluidity in the function of time were analysed in [13-15], while the selection of optimal adding time of admixture and its influence on adsorption and workability of mixtures in papers $[11,16]$.

The rheological properties of fresh cement mortars and concrete mixtures were discussed in $[17,18]$.

The influence of superplasticiser on physical and mechanical properties of pastes, mortars and concretes were analysed [1-6, 19-25].

In the available literature cited in this paper there is a lack of solid and more complex investigations into the possibilities of cement and water content reduction in concrete mixtures using superplasticizer SNF.

The aim of this paper is to present the results of investigations into cement concrete with admixture of superplasticiser SNF and control concrete, focusing on the reduction of cement and water content in concrete mixture, also in the aspect of usefulness in building practice.

The author's research presented in this paper can fill in the gaps of knowledge with respect to the determination of optimal concrete mixture composition with SNF, using minimal quantity of cement and allowing to maintain the technical characteristics of concrete on the level of control concretes. 


\section{Test and their results}

\subsection{Materials}

Ordinary superplasticiser SNF was used for experiments. It is a water solution of sodium salt of formaldehydic polycondesates of sulfonic-naphthalene acids, characterised by the oil consistency and darkbrown colour. The chemical formula of the main content is: $\mathrm{NaO}_{3} \mathrm{~S}\left(\mathrm{C}_{10} \mathrm{H}_{5}\right)-\mathrm{CH}_{2}-\left(\mathrm{C}_{10} \mathrm{H}_{6}\right) \mathrm{SO}_{3} \mathrm{Na}$. The content of dry substance in the water solution was $34 \%$ and the superplasticiser density in $+20{ }^{\circ} \mathrm{C}$ was $1,165 \mathrm{~g} / \mathrm{ml}$. Two kinds of Portland cement were used: CEM I 32,5 R and CEM 42,5 R from the Górażdże Cement Plant.

The aggregates used:

a) the gravel $8-16 \mathrm{~mm}$ from Mietków mine,

b) the gravel $2-8 \mathrm{~mm}$ from Mietków mine,

c) the sand $0-2 \mathrm{~mm}$ from Mietków mine,

d) the basalt grit $8-16 \mathrm{~mm}$ from Strzegom Graniczna,

e) the basalt grit $4-8 \mathrm{~mm}$ from Strzegom - Graniczna. Tap water was used.

The mineral aggregates were experimentally combined into an optimum aggregate compositioncharacterised by maximum compactness and minimum amount of water absorbed by the aggregate [5, 19, 23, $24]$. The voids determined for the compacted aggregates $\left(\mathrm{c}_{\mathrm{c}}\right)$ and the calculated grading index $\left(U_{K}\right)$ according to [19] amounted to respectively:

for the mineral aggregate (gravel $8 / 16+$ gravel $2 / 8+$ sand $0 / 2)-26,5 \%$ and 6,21 ,

for the granite aggregate and natural sand (grit 8/16 + grit $4 / 8+$ sand $0 / 2)-25,3 \%$ and 6,01 .

The composition of aggregates is considered to be very good when $6 \leq U_{K} \leq 7,5$ [19].

\subsection{The properties of cements used}

The testing of cement binding time was carried out on pastes with consistency [26].

Superplasticiser SNF was added together with mixing water from 0,8 to $2,0 \%$ according to the mass of cement. As a result of plasticising performance of superplasticiser the amount of water in the paste was decreased by 10,1 to $21,2 \%$, while the standard consistency was maintained.

Figs 1 and 2 reflect the relationship between the amount of removed water $(\Delta W)$ and the amount of superplasticiser.

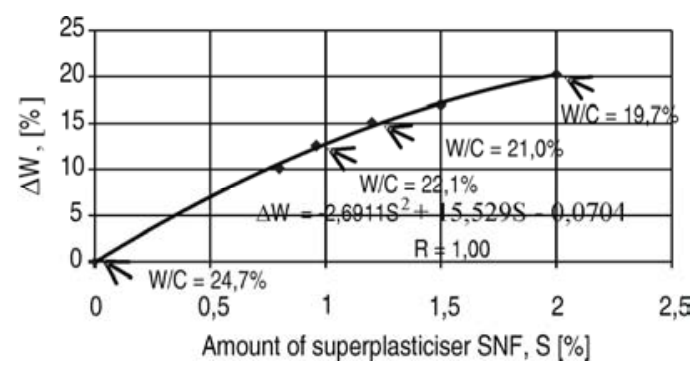

Fig 1. The superplasticiser influence on water reduction in standard paste (CEM I 32,5 R Górażdże)

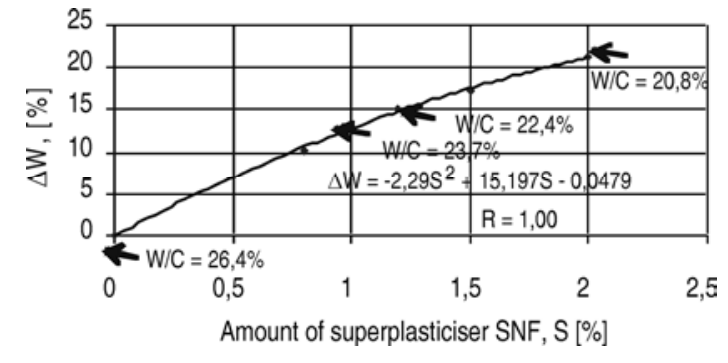

Fig 2. The superplasticiser influence on water reduction in standard paste (CEM I 42,5 R Górażdże)

The cement's chemical and phase composition is given in Table 1.

The physical and strength characteristics of cements $[27,28]$ are shown in Table 2.

Cement CEM I 32,5 R Górażdże used in the experiments corresponds to the requirements of standard [29] in accordance with the compressive strength after 2 and 28 days of hardening. On the other hand, the early and the standard compressive strength of cement CEM I 42,5 $\mathrm{R}$ was lower by 12 and $17 \%$, respectively, in comparison to standard requirements [29].

The setting time of cement was tested using pastes characterised by standard consistency [26]. Superplasticiser SNF was added to the cement together with mixing water. The results of tests by Vicat method are presented in Table 3.

\subsection{The properties of concrete mixtures with superplasticiser $\mathrm{SNF}$}

Ten concrete mixtures were made using CEM 32,5 R Górażdże and natural aggregates from Mietków mine: six of control character with V4 consistency and different quantities of cement from 190 to $350 \mathrm{~kg} / \mathrm{m}^{3}$, and four with superplasticiser SNF, which was added in the amount of $1,5 \%$ according to the mass of cement. In concrete mixtures with an admixture of a larger amount of binder, the content of water and cement was being reduced, while preserving the initial consistency V4 of concrete mixtures and $W / C$ ratio constant.

The cement paste, which was removed from the mixtures with superplasticiser SNF, was replaced by the adequate amount of component aggregates (gravel + sand) (Table 4).

Using CEM I 42,5 R Górażdże, granite aggregates from Strzegom-Graniczna and sand from Mietków mine, six concrete mixtures were made: three of control character with consistency V4 and different amounts of cement varying from 320 to $380 \mathrm{~kg} / \mathrm{m}^{3}$, and three with superplasticiser SNF, which was added in the amount of $1,5 \%$ according to the cement mass.

In mixtures with an admixture the content of cement and water was being reduced, while maintaining concrete consistency at initial level V4 and $W / C$ ratio constant. In mixtures with superplasticiser SNF the removed cement paste was replaced by an adequate amount of component aggregates (granite grit + sand) (Table 5). 
Table 1. Chemical and phase composition of Portland cements

\begin{tabular}{|c|c|c|}
\hline \multicolumn{3}{|c|}{ Chemical composition } \\
\hline \multirow{2}{*}{ Component } & \multicolumn{2}{|c|}{ Content, \% by weight } \\
\hline & CEM I 32,5 R Górażdże & CEM 42,5 RGórażdże \\
\hline $\mathrm{CaO}$ & 64,2 & 64,0 \\
\hline $\mathrm{SiO}_{2}$ & 20,2 & 20,0 \\
\hline $\mathrm{Al}_{2} \mathrm{O}_{3}$ & 5,0 & 4,9 \\
\hline $\mathrm{Fe}_{2} \mathrm{O}_{3}$ & 2,5 & 2,5 \\
\hline $\mathrm{SO}_{3}$ & 2,9 & 2,8 \\
\hline $\mathrm{MgO}$ & 1,0 & 1,2 \\
\hline $\mathrm{Na}_{2} \mathrm{O}+\mathrm{K}_{2} \mathrm{O}$ & 0,80 & 0,80 \\
\hline Roasting loss & 1,8 & 2,7 \\
\hline Soluble components & 0,9 & 0,5 \\
\hline \multicolumn{3}{|c|}{ Phase composition } \\
\hline Component & \multicolumn{2}{|c|}{ Content, $\%$ by weight } \\
\hline $\mathrm{C}_{3} \mathrm{~S}$ & \multicolumn{2}{|c|}{54,8} \\
\hline $\mathrm{C}_{2} \mathrm{~S}$ & \multicolumn{2}{|c|}{21,5} \\
\hline $\mathrm{C}_{3} \mathrm{~A}$ & \multicolumn{2}{|c|}{9,8} \\
\hline $\mathrm{C}_{4} \mathrm{AF}$ & \multicolumn{2}{|c|}{8,2} \\
\hline Free calcium $\mathrm{CaO}$ & \multicolumn{2}{|c|}{1,3} \\
\hline Minor components & \multicolumn{2}{|c|}{3,4} \\
\hline
\end{tabular}

Table 2. Physical and mechanical properties of Portland cements

\begin{tabular}{|c|c|c|c|c|}
\hline \multirow{2}{*}{ Characteristic } & \multicolumn{2}{|c|}{ The value of characteristic } & \multicolumn{2}{|c|}{$\begin{array}{l}\text { Standard requirements [12] } \\
\text { for the strength cement class }\end{array}$} \\
\hline & $\begin{array}{l}\text { CEM I } 32,5 \text { R } \\
\text { Górażdże }\end{array}$ & $\begin{array}{l}\text { CEM I 42,5 R } \\
\text { Górażdże }\end{array}$ & CEM I 32,5 R & CEM I 42,5 R \\
\hline $\begin{array}{l}\text { Compressive strength of } \\
\text { standard mortar after } 2 \text { days } \\
\text { (early) }[\mathrm{MPa}]\end{array}$ & 17,4 & 17,6 & minimum $10 \mathrm{MPa}$ & minimum 20MPa \\
\hline $\begin{array}{c}\text { Compressive strength of } \\
\text { standard mortar after } 28 \text { days } \\
\text { (standard) }[\mathrm{MPa}]\end{array}$ & 33,0 & 35,2 & $\begin{array}{l}\text { minimum } 32,5 \mathrm{MPa} \\
\text { maximum } \\
52,5 \mathrm{MPa}\end{array}$ & $\begin{array}{l}\text { minimum } 42,5 \mathrm{MPa} \\
\text { maximum } 62,5 \mathrm{MPa}\end{array}$ \\
\hline $\begin{array}{c}\text { Specific surface according to } \\
\text { Blaine'a }\left[\mathrm{m}^{2} / \mathrm{kg}\right]\end{array}$ & 306 & 324 & - & - \\
\hline Density $\left[\mathrm{kg} / \mathrm{m}^{3}\right]$ & 3140 & 3150 & - & - \\
\hline
\end{tabular}

Table 3. The plasticity and the setting time of standard pastes with SNF

\begin{tabular}{|c|c|c|c|c|c|c|}
\hline \multirow{2}{*}{$\begin{array}{l}\text { The cement } \\
\text { strength class }\end{array}$} & \multirow{2}{*}{$\begin{array}{c}\text { The amount of SNF ( } 34 \% \text { water } \\
\text { solution) as a percentage of the } \\
\text { cement mass [\%] }\end{array}$} & \multirow{2}{*}{$\begin{array}{l}W / C \\
{[\%]}\end{array}$} & \multirow{2}{*}{$\begin{array}{l}\Delta W, \\
{[\%]}\end{array}$} & \multicolumn{3}{|c|}{$\begin{array}{l}\text { Setting conditions } \\
\text { [hours } \mathrm{h} \text {, minutes '] }\end{array}$} \\
\hline & & & & $\begin{array}{c}\text { initial } \\
t_{p}\end{array}$ & $\begin{array}{c}\text { final } \\
t_{k}\end{array}$ & $\begin{array}{c}\text { setting time } \\
t_{w}\end{array}$ \\
\hline CEM I 32,5 R & $\begin{array}{c}0,0 \\
0,80 \\
1,20 \\
2,00 \\
\end{array}$ & $\begin{array}{l}24,7 \\
22,1 \\
21,0 \\
19,7\end{array}$ & $\begin{array}{c}0,0 \\
10,1 \\
15,1 \\
20,2\end{array}$ & $\begin{array}{l}\text { 4h } 20^{\prime} \\
4 \mathrm{~h} 40^{\prime} \\
5 \mathrm{~h} 10^{\prime} \\
5 \mathrm{~h} 50^{\prime}\end{array}$ & $\begin{array}{l}\text { 5h } 00^{\prime} \\
6 \text { h } 00^{\prime} \\
6 \mathrm{~h} \mathrm{20} \\
7 \mathrm{~h} 00^{\prime}\end{array}$ & $\begin{array}{l}\text { Oh } 40 \\
\text { 1h } 20^{\prime} \\
\text { 1h } 10 \\
\text { 1h } 10 \\
\end{array}$ \\
\hline CEM I 42,5 R & $\begin{array}{c}0,0 \\
0,80 \\
1,20 \\
2,00\end{array}$ & $\begin{array}{l}26,4 \\
23,7 \\
22,4 \\
20,8\end{array}$ & $\begin{array}{c}0,0 \\
10,1 \\
15,1 \\
21,2\end{array}$ & $\begin{array}{l}\text { 4h } 10^{\prime} \\
\text { 4h } 30^{\prime} \\
4 \mathrm{~h} 55^{\prime} \\
5 \mathrm{~h} 00^{\prime}\end{array}$ & $\begin{array}{l}\text { 4h } 45^{\prime} \\
5 \mathrm{~h} 30^{\prime} \\
6 \mathrm{~h} 10^{\prime} \\
6 \mathrm{~h} 30^{\prime}\end{array}$ & $\begin{array}{l}\text { Oh 35' } \\
\text { 1h } 00^{\prime} \\
\text { 1h } 15^{\prime} \\
\text { 1h } 30^{\prime}\end{array}$ \\
\hline
\end{tabular}


The choice of W/C values was based on the assumed quantity of cement in $1 \mathrm{~m}^{3}$ of concrete and the amount of water necessary to obtain the control consistency of concrete mix.

\subsection{The properties of concrete with superplasticiser SNF}

The following properties of concrete were determined: the density, the compressive strength, the water absorption, and the resistance to water penetration. The density and the resistance to water penetration were determined after 28 days of concrete hardening under laboratory conditions using 6 cube specimens with a $15 \mathrm{~cm}$ diameter for every type of concrete [30, 31]. Minimum, mean and maximum values of density and compressive strength of concretes with characteristics presented in Tables 3 and 4, are shown in Table 6 .

The water absorption was determined after 28 days of concrete hardening in the laboratory conditions using cube specimens with a $10 \mathrm{~cm}$ diameter [32], 5 specimens for every type of concrete (Table 7).

The tests of resistance to water penetration of concrete were carried out using specimens with a $30 \mathrm{~cm}$ diameter and a $15 \mathrm{~cm}$ depth $[33,34]$. The tests were made after 28 days of concrete hardening in the laboratory conditions. The pressure was being risen by $0,2 \mathrm{MPa}$ every 24 hours till the point when it reached the value of $0,8 \mathrm{MPa}$. None of the tested specimens of concrete was percolating. After carrying out tests, the specimens were split and the depth of water penetration was determined [34] (Table 8).

\section{The possibilities of cement saving in concretes with the admixture of superplasticiser SNF}

In the author's opinion, taking into account the economical aspects of superplastiser SNF usage, the possibilities of cement saving, while preserving the basic technical properties of concrete, should be considered [56 , 25]. Such analysis can be carried out for superplasticiser SNF, based on the fact that this kind of admixture allows for the significant reduction of mixing water, and for the maintenance of initial concrete mixture consistency and the quality of concrete at the same time.

The investigations were mainly performed to answer the question, whether the results of experiments on the effectiveness of superplasticiser SNF usage can be helpful in building practice. While applying this kind of admixture in cement material, the following assumption was made: the mean compressive strength of concrete after 28 days of hardening is going to maintain at the same level as for the control concrete. Basing on the formula of Bolomey, the contents of concretes with and without admixture and with the same compressive strength were settled. In concrete mixtures with SNF, the amount of mixing water and cement was reduced, maintaining the initial $W / C$ ratio and consistency constant (Tables 4 and 5).
Hence, assuming that

$$
K_{O}=K_{S N F} \quad \text { and } \quad f_{c}=f_{c m 28}=f_{c m 28 S N F}
$$

and using the formula for compressive strength, we have obtained:

$$
f_{c m 28}=A\left(\frac{C 1}{W 1}-0,5\right)
$$

- for concrete mixture $M$ (without admixture),

$$
\begin{aligned}
f_{c m 28 S N F} & =A\left(\frac{C 1-\Delta C 1_{S N F}+S_{S N F}}{W 1-\Delta W 1_{S N F}}-0,5\right)= \\
& =A\left(\frac{C 1_{S N F}+S_{S N F}}{W 1_{S N F}}-0,5\right)
\end{aligned}
$$

- for concrete mixture $M_{S N F}$ (with a superplasticiser).

Comparing formulas (1) and (2), the difference between cement contents in both concretes can be calculated $\left(\Delta C 1_{S N F}\right)$ :

$$
\Delta C 1_{S N F}=\frac{C 1}{W 1} \times \Delta W 1_{\mathrm{SNF}}+S_{S N F} .
$$

The quantity of cement used in the mixture with superplasticiser SNF will equal to:

$$
C 1_{S N F}=C 1-\Delta C 1_{S N F},
$$

where:

$K_{0}$ - the consistency of mixture without admixture, expressed by Vebe time, in s, expressed by slump, in mm, $K_{S N F}$ - the consistency of mixture with superplasticiser $\mathrm{SNF}$, expressed by Vebe time, in s, expressed by slump, in $\mathrm{mm}$,

$f_{\mathrm{cm} 28}$ - the mean compressive strength after 28 days of hardening of concrete formed from mixture without admixture (control mixture), MPa,

$f_{c m 28 S N F}$ - the mean compressive strength after 28 days of hardening of concrete formed from mixture with admixture of SNF, MPa,

$C 1$ - the quantity of cement in the mixture without admixture (control mixture), $\mathrm{kg}$,

$W 1$ - the quantity of water in the mixture without admixture (control mixture), $\mathrm{kg}$,

$\Delta \mathrm{Cl}_{S N F}$ - the reduction of the cement quantity in the mixture with superplasticiser SNF,

$\Delta \mathrm{W} 1_{S N F}$ - the reduction of the water quantity in the mixture with superplasticiser SNF,

$C 1_{S N F}$ - the quantity of cement in the mixture with superplasticiser SNF, kg,

$W 1_{S N F}$ - the quantity of water in the mixture with superplasticiser SNF, $\mathrm{kg}\left(\mathrm{dm}^{3}\right)$,

$S_{S N F}$ - the quantity of superplasticiser SNF, kg.

After taking into account the contents of experimental mixtures and the determined mean compressive strength of concrete after 28 day of hardening, the saving of cement in the mixture with the superplasticiser SNF was calculated. 


\begin{tabular}{|c|c|c|c|c|c|c|c|c|c|c|}
\hline 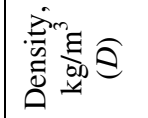 & 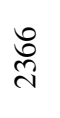 & $\begin{array}{l}\infty \\
\stackrel{\infty}{\approx} \\
\end{array}$ & $\begin{array}{l}\infty \\
\tilde{\lambda}^{2}\end{array}$ & $\underset{\mathrm{d}}{\stackrel{\mathrm{J}}{\mathrm{d}}}$ & 京 & 客 & $\begin{array}{l}\vec{\infty} \\
\underset{\sim}{\alpha}\end{array}$ & 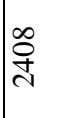 & 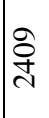 & $\stackrel{\infty}{\stackrel{+}{+}}$ \\
\hline$=\frac{\overrightarrow{\tilde{E}}}{0}$ & $\ddot{n}$ & ma & m. & $\overrightarrow{0}$ & $\delta_{0}^{2}$ & $z_{0}^{2}$ & $\begin{array}{l}0 \\
0 \\
0\end{array}$ & $\stackrel{t}{0}$ & $\hat{o}$ & $\infty$ \\
\hline 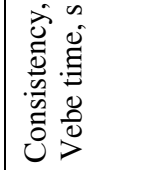 & $\stackrel{n}{n}$ & $\stackrel{\circ}{r}$ & $\dot{m}$ & $\dot{m}$ & $\dot{m}$ & $\stackrel{\circ}{\circ}$ & $\stackrel{\circ}{*}$ & 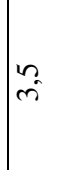 & $\theta_{0}$ & ? \\
\hline 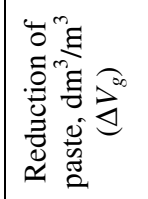 & 1 & 1 & 1 & 1 & 1 & 1 & $\begin{array}{l}n \\
\text { ñ } \\
m\end{array}$ & $\begin{array}{c}0 \\
i n \\
f\end{array}$ & $\stackrel{\substack{n \\
n}}{n}$ & $\begin{array}{l}\infty \\
\text { in } \\
\text { in }\end{array}$ \\
\hline
\end{tabular}

\begin{tabular}{|c|c|c|c|c|c|c|}
\hline 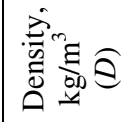 & & 旁 & $\frac{n}{7}$ & 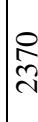 & శે & \\
\hline 安莺。 & $\tilde{o}^{2}$ & $\tilde{n}_{0}^{2}$ & $\overrightarrow{0}$ & $\stackrel{0}{\circ}$ & 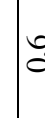 & \\
\hline 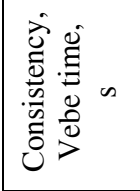 & $\begin{array}{l}0 \\
i n\end{array}$ & $\stackrel{n}{f}$ & $\underset{f}{0}$ & $\stackrel{\circ}{i}$ & $\mid \begin{array}{c}0 \\
0\end{array}$ & \\
\hline 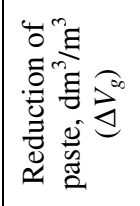 & 1 & 1 & 1 & $\stackrel{\infty}{\infty}$ & $\mid \begin{array}{l}\infty \\
i=0\end{array}$ & \\
\hline
\end{tabular}

\begin{tabular}{|c|c|c|c|c|c|c|c|c|c|c|}
\hline 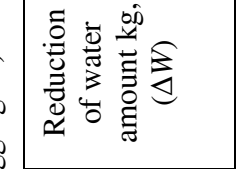 & 1 & 1 & 1 & 1 & 1 & 1 & $\stackrel{\infty}{\sim}$ & $\bar{m}$ & "ా & ले \\
\hline 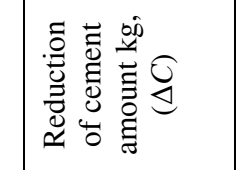 & 1 & 1 & 1 & 1 & 1 & 1 & $m$ & 寸 & it & in \\
\hline$\frac{\bigcup}{3}$ & $\stackrel{0}{\circ}$ & $\begin{array}{l}\check{2} \\
\hat{\sigma} \\
\hat{\sigma}\end{array}$ & $\frac{m}{\infty}$ & $\frac{8}{0}$ & శ్రి & $\begin{array}{l}\infty \\
\infty \\
n \\
0 \\
0\end{array}$ & $\begin{array}{l}m \\
\infty \\
0 \\
0\end{array}$ & ô. & $\begin{array}{l}\text { त్రి } \\
\text { ¿. }\end{array}$ & $\begin{array}{l}0 \\
0 \\
0 \\
0 \\
0\end{array}$ \\
\hline 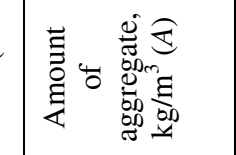 & 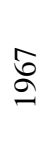 & 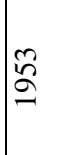 & $\tilde{\curvearrowright}$ & $\frac{\approx}{\partial}$ & $\begin{array}{l}\infty \\
\infty \\
\stackrel{\infty}{\infty}\end{array}$ & $\mid \begin{array}{l}\infty \\
\infty \\
\infty\end{array}$ & $\vec{\infty}$ & $\vec{\infty}$ & $\underset{\mathfrak{S}}{\stackrel{2}{2}}$ & 号 \\
\hline 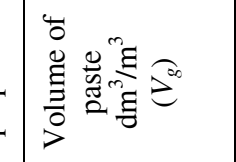 & 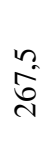 & $\begin{array}{l}\infty \\
\infty \\
\hat{\lambda} \\
\hat{\lambda}\end{array}$ & $\begin{array}{l}\text { in } \\
\infty \\
\infty \\
\text { in }\end{array}$ & 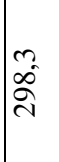 & $\begin{array}{l}\tilde{z} \\
\hat{\delta} \\
\tilde{n}\end{array}$ & $\overrightarrow{\vec{g}^{\prime}}$ & $\overrightarrow{\tilde{j}}$ & \begin{tabular}{l}
$m$ \\
\multirow{n}{n}{}
\end{tabular} & $\frac{0}{\vec{n}}$ & 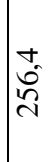 \\
\hline 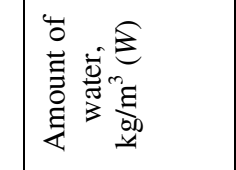 & 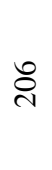 & $\frac{\mathrm{N}}{\mathrm{N}}$ & 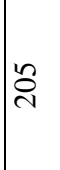 & $\stackrel{\sim}{\sim}$ & $\underset{\sim}{~}$ & $\stackrel{\infty}{\sigma}$ & $\stackrel{\infty}{=}$ & $\stackrel{ \pm}{I}$ & $\underset{\overbrace{}}{\circ}$ & ț \\
\hline 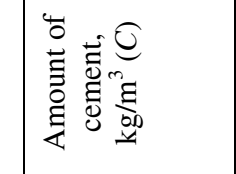 & $\stackrel{\varrho}{\Omega}$ & $\stackrel{m}{\vec{v}}$ & సิ & $\hat{\text { ते }}$ & $\overrightarrow{\widetilde{N}}$ & 商 & $\frac{\partial}{\vec{\lambda}}$ & 공 & $\sqrt{0}$ & ì \\
\hline 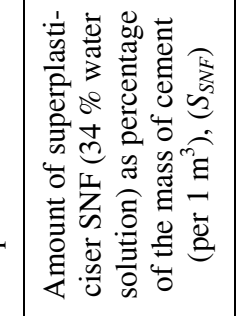 & 1 & 1 & 1 & 1 & 1 & 1 & $\begin{array}{l}0 \\
0 \\
n \\
0 \\
n \\
n \\
-1\end{array}$ & $\begin{array}{l}\overparen{f} \\
\stackrel{d}{c} \\
\underline{n} \\
\stackrel{-}{1}\end{array}$ & 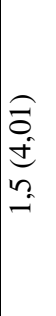 & 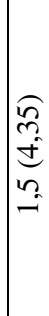 \\
\hline 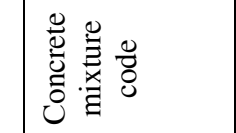 & $\bar{U}$ & U & $\tilde{U}$ & U & $\ddot{0}$ & 8 & లే & 孚 & 芯 & U \\
\hline
\end{tabular}

\begin{tabular}{|c|c|c|c|c|c|c|c|}
\hline & 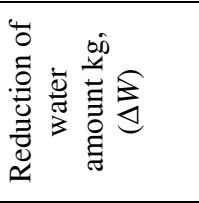 & 1 & 1 & 1 & $\tilde{m}$ & $m$ & $m$ \\
\hline & 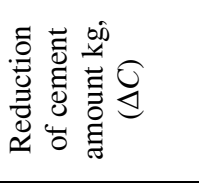 & 1 & 1 & 1 & in & $\stackrel{i}{n}$ & $\overline{0}$ \\
\hline & 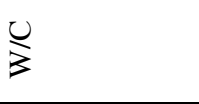 & $\stackrel{1}{\sigma}$ & $\begin{array}{l}+ \\
\text { in } \\
0 \\
0\end{array}$ & $\mid \begin{array}{l}\hat{n} \\
\hat{n} \\
0\end{array}$ & $\begin{array}{l} \pm \\
\\
0 \\
0\end{array}$ & त्र & $\mid \begin{array}{l}0 \\
\tilde{n} \\
0 \\
0\end{array}$ \\
\hline & 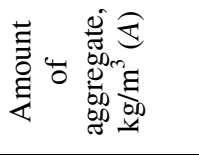 & $\stackrel{\hat{\theta}}{\underline{\infty}}$ & $\begin{array}{l}\infty \\
\infty \\
\infty\end{array}$ & $\mid \vec{\infty}$ & 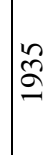 & $\stackrel{\infty}{\stackrel{2}{\Omega}}$ & $\stackrel{\infty}{0}$ \\
\hline & 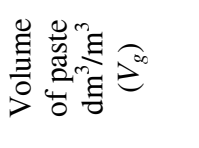 & 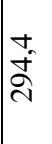 & $\overrightarrow{\bar{m}}$ & $\begin{array}{l}0 \\
\stackrel{0}{\tilde{m}}\end{array}$ & 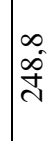 & m. & $\mid \begin{array}{l}\tilde{N} \\
\hat{N}\end{array}$ \\
\hline & 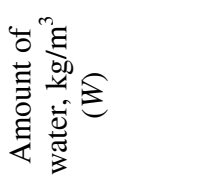 & ‡ & $\vec{\sim}$ & $\underset{\sim}{+}$ & $\underset{\sigma}{\mathbb{t}}$ & $\stackrel{\infty}{\infty}$ & $\Xi$ \\
\hline & 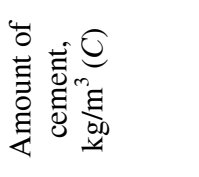 & లి & $\stackrel{n}{n}$ & $\stackrel{\infty}{\infty}$ & స్ & ¿্ & $\frac{\partial}{m}$ \\
\hline & 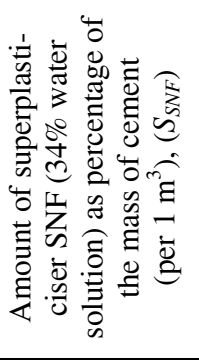 & 1 & 1 & 1 & 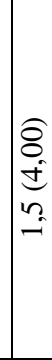 & $\overrightarrow{7}$ & 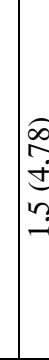 \\
\hline & 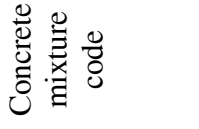 & $\hat{U}$ & రి & రे & 苍 & 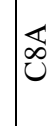 & 8 \\
\hline
\end{tabular}


Table 6. Density and compressive strength of concrete with admixture of superplasticiser SNF after 28 days of hardening under laboratory conditions

\begin{tabular}{|c|c|c|c|c|c|}
\hline \multirow{2}{*}{ Concrete mixture code } & \multirow{2}{*}{ Density, in $\mathrm{kg} / \mathrm{m}^{3}\left(D_{c m}\right)$} & \multicolumn{3}{|c|}{ Compressive strength, in $\mathrm{MPa}\left(f_{c}\right)$} & \multirow{2}{*}{$\begin{array}{c}\text { Compressive strength class } \\
\text { [35] }\end{array}$} \\
\hline & & $f_{\text {cimin }}$ & $f_{\text {cimax }}$ & $f_{c m}$ & \\
\hline $\mathrm{C} 1$ & 2240 & 12,7 & 14,8 & 14,0 & $\mathrm{C} 8 / \mathrm{C} 10$ \\
\hline $\mathrm{C} 2$ & 2250 & 15,6 & 17,0 & 16,4 & $\begin{array}{c}\mathrm{C} 8 / \mathrm{C} 10 \\
\mathrm{C} 12 / 15>\mathrm{C}_{\mathrm{C} 2}>\mathrm{C} 8 / 10\end{array}$ \\
\hline $\mathrm{C} 3$ & 2286 & 22,6 & 25,3 & 23,8 & $\mathrm{C} 16 / 20$ \\
\hline $\mathrm{C} 4$ & 2294 & 26,5 & 29,5 & 28,1 & $\begin{array}{c}\mathrm{C} 16 / 20 \\
\mathrm{C} 20 / 25>\mathrm{C}_{\mathrm{C} 4}>\mathrm{C} 16 / 20\end{array}$ \\
\hline $\mathrm{C} 5$ & 2294 & 33,8 & 35,1 & 34,2 & $\mathrm{C} 25 / 30$ \\
\hline C6 & 2297 & 35,8 & 38,8 & 37,3 & $\begin{array}{c}\mathrm{C} 25 / 30 \\
\mathrm{C} 30 / 37>\mathrm{C}_{\mathrm{C} 6}>\mathrm{C} 25 / 30\end{array}$ \\
\hline $\mathrm{C} 3 \mathrm{~A}$ & 2285 & 22,8 & 25,2 & 23,9 & $\mathrm{C} 16 / 20$ \\
\hline $\mathrm{C} 4 \mathrm{~A}$ & 2294 & 26,6 & 30,0 & 27,7 & $\begin{array}{c}\mathrm{C} 16 / 20 \\
\mathrm{C} 20 / 25>\mathrm{C}_{\mathrm{C} 4 \mathrm{~A}}>\mathrm{C} 16 / 20 \\
\end{array}$ \\
\hline $\mathrm{C} 5 \mathrm{~A}$ & 2311 & 35,2 & 36,6 & 35,8 & $\mathrm{C} 25 / 30$ \\
\hline C6A & 2304 & 36,6 & 39,9 & 38,3 & $\begin{array}{c}\mathrm{C} 25 / 30 \\
\mathrm{C} 30 / 37>\mathrm{C}_{\mathrm{C} 6 \mathrm{~A}}>\mathrm{C} 25 / 30 \\
\end{array}$ \\
\hline $\mathrm{C} 7$ & 2302 & 37,5 & 39,4 & 38,0 & $\begin{array}{c}\mathrm{C} 25 / 30 \\
\mathrm{C} 30 / 37>\mathrm{C}_{\mathrm{C} 7}>\mathrm{C} 25 / 30 \\
\end{array}$ \\
\hline $\mathrm{C} 8$ & 2328 & 42,1 & 44,4 & 42,9 & $\mathrm{C} 30 / 37$ \\
\hline C9 & 2327 & 45,2 & 46,4 & 45,8 & $\begin{array}{c}\mathrm{C} 30 / 37 \\
\mathrm{C} 35 / 45>\mathrm{C}_{\mathrm{C} 9}>\mathrm{C} 30 / 37 \\
\end{array}$ \\
\hline C7A & 2294 & 37,4 & 39,6 & 38,2 & $\begin{array}{c}\mathrm{C} 25 / 30 \\
\mathrm{C} 30 / 37>\mathrm{C}_{\mathrm{C} 7 \mathrm{~A}}>\mathrm{C} 25 / 30\end{array}$ \\
\hline C8A & 2316 & 41,9 & 43,1 & 42,9 & $\mathrm{C} 30 / 37$ \\
\hline C9A & 2320 & 45,1 & 46,3 & 45,9 & $\begin{array}{c}\mathrm{C} 30 / 37 \\
\mathrm{C} 35 / 45>\mathrm{C}_{\mathrm{C} 9 \mathrm{~A}}>\mathrm{C} 30 / 37\end{array}$ \\
\hline
\end{tabular}

Table 7. Mean water absorption of concrete $\left(A_{w}\right)$ with admixture of superplasticiser SNF after 28 days of concrete hardening under laboratory conditions.

\begin{tabular}{|c|c|}
\hline $\begin{array}{c}\text { Concrete mixture } \\
\text { code }\end{array}$ & $\begin{array}{c}\text { Water absorption, } \\
\%\left(A_{w}\right)\end{array}$ \\
\hline C1 & 6,05 \\
\hline C2 & 5,80 \\
\hline C3 & 5,30 \\
\hline C4 & 5,15 \\
\hline C5 & 4,81 \\
\hline C6 & 4,63 \\
\hline C3A & 5,21 \\
\hline C4A & 4,93 \\
\hline C5A & 4,70 \\
\hline C6A & 4,51 \\
\hline C7 & 4,70 \\
\hline C 8 & 4,65 \\
\hline C9 & 4,60 \\
\hline C7A & 4,71 \\
\hline C8A & 4,55 \\
\hline C9A & 4,48 \\
\hline
\end{tabular}

In order to estimate the benefits of superplasticiser SNF usage, the index of cement saving $\mathrm{S}_{\mathrm{c}}$ was calculated

$$
S_{c}=\frac{C 1_{S N F}}{\Delta C 1_{S N F}} .
$$

This index is a ratio of the cement quantity in $1 \mathrm{~m}^{3}$ of concrete mixture with superplasticiser SNF to the quantity of cement saved in this mixture, which allows to
Table 8. Resistance to water penetration of concrete with admixture of superplasticiser SNF

\begin{tabular}{|c|c|}
\hline $\begin{array}{c}\text { Concrete mixture } \\
\text { code }\end{array}$ & $\begin{array}{c}\text { Depth of water penetration } \\
\text { under pressure } 0,8 \mathrm{MPa}, \\
\mathrm{mm}\left(\mathrm{h}_{\mathrm{w}}\right)\end{array}$ \\
\hline $\mathrm{C} 4$ & $70,69,74$ mean 71 \\
\hline $\mathrm{C} 5$ & $30,28,31$ mean 30 \\
\hline C6 & $27,28,27$ mean 27 \\
\hline C4A & $79,80,80$ mean 80 \\
\hline C5A & $36,40,41$ mean 39 \\
\hline C6A & $29,28,27$ mean 28 \\
\hline C7 & $77,75,73$ mean 75 \\
\hline C8 & $41,45,45$ mean 44 \\
\hline C9 & $33,35,35$ mean 34 \\
\hline C7A & $74,76,75$ mean 75 \\
\hline C8A & $45,46,47$ mean 46 \\
\hline C9A & $36,37,39$ mean 37 \\
\hline
\end{tabular}

obtain the assumed (the same as for the control concrete) mean compressive strength of concrete after 28 days of hardening. The index $\mathrm{S}_{\mathrm{c}}$ defines the number of $\mathrm{m}^{3}$ of mixture with superplasticiser SNF, from which it is possible to make additional $1 \mathrm{~m}^{3}$ of concrete mixture (with admixture), because of cement saving (Table 9).

For example, when $1,5 \%$ of superplasticiser was added to concrete C6 A, for every $4,91 \mathrm{~m}^{3}$ of concrete with this admixture, the quantity of cement saved equals 
to the quantity of cement which allows for making the additional $1 \mathrm{~m}^{3}$ of concrete mixture (with superplasticiser $\mathrm{SNF}$ ).

Moreover, to estimate the economical effect of superplasticiser SNF adding, the index of effective usage of cement in concretes $I_{e c}$ can be utilised:

$$
\begin{gathered}
I_{e c}=\frac{f_{c m 28}}{C 1}\left(\frac{M P a}{k g}\right), \\
I_{e c S N F}=\frac{f_{c m 28 S N F}}{C 1_{S N F}}\left(\frac{M P a}{k g}\right),
\end{gathered}
$$

in which:

$f_{\mathrm{cm} 28}, f_{c m 28 S N F}, C 1$ and $C 1_{S N F}$ - the denotations like for index $S_{c}$. The index $I_{e c}$ expresses the value of mean compressive strength of concrete without admixture or with superplasticiser SNF after 28 days of hardening, obtained after using the quantity of cement in $1 \mathrm{~m}^{3}$ of mixture without an admixture or with a superplasticiser (the value of compressive strength obtained from one kilogram of cement used in concrete) (Table 9).

Table 9. The characteristics determining savings when concrete with superplasticiser SNF is used

\begin{tabular}{|c|c|c|}
\hline \multirow{2}{*}{ Concrete mixture code } & \multicolumn{2}{|c|}{ Characteristic } \\
\cline { 2 - 3 } & $S_{c}$ & $I_{e c}$, in MPa/kg \\
\hline C1 & - & 0,0725 \\
\hline C2 & - & 0,0770 \\
\hline C3 & - & 0,0944 \\
\hline C4 & - & 0,0945 \\
\hline C5 & - & 0,1065 \\
\hline C6 & - & 0,1069 \\
\hline C3A & 6,64 & 0,1091 \\
\hline C4A & 5,66 & 0,1112 \\
\hline C5A & 4,94 & 0,1341 \\
\hline C6A & 4,91 & 0,1321 \\
\hline C7 & - & 0,1144 \\
\hline C8 & - & 0,1226 \\
\hline C9 & - & 0,1205 \\
\hline C7A & 5,04 & 0,1431 \\
\hline C8A & 5,25 & 0,1459 \\
\hline C9A & 5,23 & 0,1439 \\
\hline
\end{tabular}

The analysed indexes $S_{c}$ and $I_{e c}$ are not fully capturing the issue of economical effectiveness of concrete with superplasticiser SNF.

The economical effectiveness of superplasticiser SNF usage can be also expressed as a unit cost of basic effect caused by a certain quantity of admixture (the desired effect obtained at the smallest cost). Therefore, it is possible to calculate the change in the production cost of $1 \mathrm{~m}^{3}$ of concrete mixture when superplasticiser SNF is used in comparison to control concrete mixture, while taking into account the changes in the quantities of basic components: cement, water and aggregates. In concretes with admixtures $\mathrm{C} 3 \mathrm{~A}, \mathrm{C} 4 \mathrm{~A}, \mathrm{C} 5 \mathrm{~A}, \mathrm{C} 6 \mathrm{~A}, \mathrm{C} 7 \mathrm{~A}, \mathrm{C} 8 \mathrm{~A}$ and C9A, a certain quantity of cement and water was removed and adequate proportions of component aggregates and superplasticiser were added (Tables 4, 5). Such a cost estimation of admixture usage can be related to existing material conditions when a concrete with certain characteristics is produced. The cost of effect of superplasticiser usage can be also connected with transportation, storage and placing of concrete.

Together with economical effectiveness estimation, the technical effectiveness should be also considered. The technical effectiveness can be calculated, for example, as a ratio of demanded basic effect (the change in technical properties of concrete: compressive strength or water absorption, resistance to freezing, resistance to water penetration, shrinkage etc) and minimal quantity of admixture necessary to cause this effect.

\section{Discussion of results}

Analysing the results of investigations, we can conclude that SNF addition influences the plasticising of cement material. For example, in standard pastes, when adding $0,8-2,0 \%$ of admixture, it is possible to reduce the amount of water by $10-21 \%$ and preserve the standard consistency (Table 3 and Figs 1 and 2).

In cement concretes containing mineral and granite aggregates with mineral sand, it is possible to reduce the amount of water by 13 to $18 \%$ after adding $1,5 \%$ of superplasticiser, while decreasing the share of cement (maintaining W/C ratio constant) (Tables 4,5 ). The plasticising with an admixture is more effective for concretes containing bigger amounts of cement.

It is crucial to add that standard PN-EN 934-2 [36] is differentiating between two groups of water-reducing admixtures distinguished according to following criteria:

a) plasticisers - allowing for the water reduction in concrete mixture by not less than $5 \%$ in comparison to control concrete mixture;

b) superplasticisers - allowing for the water reduction in concrete mixture by not less than $12 \%$ in comparison to control concrete mixture.

Superplasticiser SNF air-entrains the concrete mixtures to a small extent, at maximum $0,7 \%$ (Tables 4,5 ).

A significant influence of SNF on concrete mixtures density was not found.

When an admixture was added only in the quantity of $0,8-2,0 \%$, the initial time of cement setting has been prolonged by 20 to 90 minutes, while the final time - by 60 to $120 \mathrm{~min}$. A bigger influence of SNF was found in pastes prepared from CEM I 32,5 R Górażdże, which is associated with the smaller fineness of this binder in comparison to CEM I 42,5 \% R Górażdże (Table 3).

The results of density and compressive strength tests of control concretes and concretes with a superplasticiser addition (Table 6) indicate the significant influence of this admixture on the compressive strength after 28 days of concrete hardening. At the same time the removal of adequate amount of cement and water from concretes $\mathrm{C} 3$, C4, C5, C6, C7, C8 and C9 (Tables 4, 5), while sustaining W/C ratio constant, causes the maintenance of compressive strength at the level of compressive strength of concretes without an admixture. 
The results of compressive strength tests of concretes with a superplasticiser admixture in association with possibility of cement saving are analysed broader in Chapter 3 of this paper.

The water absorption of control concretes and with addition of a plasticiser is comparable.

According to standard [32] the water absorption of concrete should not be higher than:

- $5 \%$ - for concretes exposed to environmental actions,

- $9 \%$ - for concretes protected against environmental actions.

All analysed concretes prepared using granite aggregates keep the requirements of standard [32] in accordance with both types of cement concrete work. Among concretes made using mineral aggregates, the requirements of standard [32] are fulfilled by only two of control concretes (C5 and C6 with the biggest content of cement), concretes with a reduced amount of water and cement and with SNF addition (C4A, C5A and C6A).

The tests of resistance to water penetration were carried out using the maximum pressure of water on concrete of $0,8 \mathrm{MPa}$. Analysing the results in Table 8 it can be concluded that all tested concretes reached the resistance to water penetration level of degree W8. The only differences observed are in the depth of water penetration under pressure.

\section{Conclusions}

From the tests on concrete pastes with the superplasticiser SNF the following conclusions can be drawn.

1. The admixture used in the quantity varying from 0,8 to $2,0 \%$ according to the mass of cement, has a very strong plasticising effect, which allows for the water reduction in pastes by 10 to $21 \%$ while maintaining standard consistency. The addition of $1,5 \%$ of superplasticiser reduces the amount of water by 13 to $18 \%$ in concrete mixtures made from natural and granite aggregates and at the same time decreases the cement share, while maintaining $\mathrm{W} / \mathrm{C}$ ratio constant and consistency of concrete mixture at initial level. Superplasticiser SNF can be considered as a waterreducing admixture according to the classification criteria given in standard [35].

2. The admixture addition in the quantity of $0,8-$ $2,0 \%$ results in lengthening the setting time of Portland cements $32,5 \mathrm{R}$ and $42,5 \mathrm{R}$ from Górażdże. It was observed that the initial setting time was prolonged by 20 to 90 minutes, while final setting time by 60 to 120 minutes. While having similar chemical composition, the differences in setting times of both binders are caused by their fineness (Table 2 - degree of fineness according to Blaine'a). In order to use the results of investigations into setting time of cements with a superplasticiser in building practice, the empirical relations from the literature can be used, which allow to determine the fluidity of concrete mixture in the function of its setting time [5].
3. The admixture in the amount of $1,5 \%$ according to cement mass allows cement saving and reduction of water content at the same time:

a) for concretes from mineral aggregates $34 \mathrm{dm}^{3}$,

$\Delta C$ from 33 to $59 \mathrm{~kg} / \mathrm{m}^{3}$ and $\Delta W$ from 27 to

b) for concretes from granite aggregates $33 \mathrm{dm}^{3}$.

$\Delta C$ from 53 to $61 \mathrm{~kg} / \mathrm{m}^{3}$ and $\Delta W$ from 32 to

This kind of superplasticiser SNF addition allows to maintain the consistency and the density at the initial level and the compressive strength at the level of control concrete.

4. The introduction of $1,5 \%$ of SNF and parallel reduction of water quantity to maintain control consistency of mix (W/C constant), does not influence the values of water absorption and resistance to water penetration with the water pressure of $0,8 \mathrm{MPa}$.

5. In order to estimate the economical effectiveness of admixture, the following indexes can be used: the index of cement saving $S_{c}$ and the index of effectiveness of cement usage in concretes $I_{e c}$. Basing on tests, we can conclude that as a result of SNF addition in the amount of $1,5 \%$, the quantity of cement in concrete mixtures was reduced:

a) containing mineral aggregates - from $252-$ $321 \mathrm{~kg} / \mathrm{m}^{3}$ to $219-290 \mathrm{~kg} / \mathrm{m}^{3}$ and the values of $S_{c}$ calculated are varying between 6,64 and 4,91,

b) containing granite aggregates - from $320-$ $380 \mathrm{~kg} / \mathrm{m}^{3}$ to $267-319 \mathrm{~kg} / \mathrm{m}^{3}$ and the values of $S_{c}$ are between 5,25 and 5,04.

It implies that for $4,91-6,64 \mathrm{~m}^{3}$ of concrete mixture with mineral aggregate $\left(\mathrm{C}=219-290 \mathrm{~kg} / \mathrm{m}^{3}\right)$ and till $5,04-5,25 \mathrm{~m}^{3}$ of concrete mixture with granite aggregate $\left(\mathrm{C}=267-319 \mathrm{~kg} / \mathrm{m}^{3}\right)$ the amount of cement saved equals to the amount of cement from which additional $1 \mathrm{~m}^{3}$ of concrete mixture with admixture could be prepared.

Moreover, by the tests results we can conclude that SNF addition in the amount of 1,5\% allows for bigger cement saving in concrete mixtures with a bigger content of binder. The calculated values of $I_{e c}$ indexes are expressing the value of mean compressive strength for one kilogram of cement used in concrete.

\section{References}

1. Ramachandran, V. S. Concrete admixtures handbook: properties, science and technology. $2^{\text {nd }}$ ed. New Jersey: Noyes Publications, 1984. 626 p.

2. Rixom, R.; and Mailvaganam, N. Chemical admixtures for concrete. London: E\&FN SPON, 1999. 456 p.

3. Dodson, V. H. Concrete admixtures. Ed., New York: Van Nostrand Reinhold, 1990. 208 p.

4. Neville, A. M. Properties of concrete (Właściwości Betonu). Cracow: Polski Cement, 2000. 874 p. (in Polish).

5. Kapelko, A. Technical and economic conditions of cement substances modification with selected chemical admixtures. Monograph. Wrocław: Wrocław University of Technology Press, 1992. 219 p. (in Polish). 
6. Papayianni, I.; Tsohos, G.; Oikonomou, N. and Mavria, P. Influence of superplasticizer type and mix design parameters on the performance of them in concrete mixtures. Cement and Concrete Composites, 27(2), 2005, p. 217-222.

7. Uchikawa, H.; Sawaki, D. and Hanehara, S. Influence of kind and added timing of organic admixture on the composition, structure and property of fresh cement paste. Cement and Concrete Research, 25(2), 1995, p. 353-364.

8. Kim, B.; Jiang, S.; Jolicoeur, C. and Aitcin, P. The adsorption behaviour of PNS superplasticizer and its relation to fluidity of cement paste. Cement and Concrete Research, 30(6), 2000, p. 887-893.

9. Khatib, J. M. and Mangat, P. S. Influence of superplasticizer and curing on porosity and pore structure of cement paste. Cement and Concrete Composites, 21(5-6), 1999, p. 431-437.

10. Termkhajornkit, P. and Nawa, T. The fluidity of fly ashcement paste containing naphthalene sulfonate superplasticizer. Cement and Concrete Research, 34(6), 2004, p. 1017-1024.

11. Agarwal, S. K.; Masood, I. and Malhotra, S.K. Compatibility of superplasticizers with different cements. Construction and Building Materials, 14(5), 2000, p. 253-259.

12. Erdogdu, S.. Compatibility of superplasticizers with cements different in composition. Cement and Concrete Research, 30(5), 2000, p. 767-773.

13. Chandra, S. and Björnström, J. Influence of cement and superplasticizers type and dosage on the fluidity of cement mortars - part I. Cement and Concrete Research, 32(10), 2002, p. 1605-1611.

14. Chandra, S. and Björnström J. Influence of superplasticizer type and dosage on the slump loss of portland cement mortars - part II. Cement and Concrete Research, 32(10), 2002, p. 1613-1619.

15. Soroka, I. and Ravina, D. Hot weather concreting with admixtures, Cement and Concrete Composites, 20(2-3), 1998, p. 129-136.

16. Uchikawa, H.; Hanehara, S. and Sawaki, D. The role of steric repulsive force in the dispersion of cement particles in fresh paste prepared with organic admixture. Cement and Concrete Research, 27(1), 1997, p. 37-50.

17. Papo, A. and Piani, L. Effect of various superplasticizers on the rheological properties of portland cement pastes. Cement and Concrete Research, 34(11), 2004, p. 2097-2101.

18. Gołaszewski, J. and Szwabowski J. Influence of superplasticizers on rheological behavior of fresh cement mortars. Cement and Concrete Research, 34(2), 2004, p. 235-248.

19. Kuczyński, W. et al. Building concrete. Vol 1, Concrete technology, part 2 (Budownictwo betonowe. Tom 1, Technologia betonu, część 2). Warszawa: Arkady, 1972. 656 p. (in Polish).
20. Kapelko, A. Estimation of the effect of additions on the strength of cement pastes and concretes. Cement-LimeGypsum (Cement-Wapno-Gips), No 9, 1985, p. 241247 (in Polish).

21. Kapelko, A. Quality of cement materials with addition of two plastifiers. Cement-Lime-Gypsum (Cement-WapnoGips), No 10, 1985, p. 276-278 (in Polish).

22. Kapelko, A. Properties of steam cured cement mortars modified with plasticizers, Cement-Lime-Gypsum (Cement-Wapno-Gips), No 3, 1988, p. 64-67 (in Polish).

23. Kapelko, A. and Młodecki, J. Possibilities of modification of concrete properties using „Betoplast 1" superplastifying admixture. Cement-Lime-Gypsum (Cement-Wapno-Gips), No 10, 1988, p. 226-228 (in Polish).

24. Kapelko, A. Special concretes used in lining of pit shafts in copper mines. Cement-Lime-Gypsum (CementWapno-Gips), No 1, 1994, p. 11-17 (in Polish).

25. Kapelko, A. The effect of a new set-retarding superplasticizer on the properties of cement-based materials. Cement-Lime-Concrete (Cement-WapnoBeton), No 3, 1999, p. 75-80 (in Polish).

26. EN 196-3:2005. Methods of testing cement - Part 3: Determination of setting time and soundness. European Committee for Standardization, Brussels, Belgium, 2005.

27. EN 196-1:2005. Methods of testing cement - Part 1: Determination of strength. European Committee for Standardization, Brussels, Belgium, 2005.

28. EN 196-6:1989. Methods of testing cement - Part 6: Determination of fineness. European Committee for Standardization, Brussels, Belgium, 1989.

29. EN 197-1:2000. Cement - Part 1: Composition, specifications and conformity criteria for common cements. European Committee for Standardization, Brussels, Belgium, 2000.

30. EN 12350-6:1999. Testing fresh concrete - Part 6: Density test. European Committee for Standardization, Brussels, Belgium, 1999.

31. EN 12390-3:2001. Testing hardened concrete - Part 3: Compressive strength of test specimens. European Committee for Standardization, Brussels, Belgium, 2001.

32. PN-88/B-06250. Polish Standard: Ordinary concrete. Polish Committee for Standardization, Warsaw, Poland, 1988. 17 p. (in Polish).

33. BN-62/6738-07. Hydrotechnical concrete. Investigation of concrete (in Polish).

34. EN 12390-8:2000. Testing hardened concrete - Part 8: Depth of penetration of water under pressure. European Committee for Standardization, Brussels, Belgium, 2000.

35. EN 206-1:2000. Concrete - Part 1: Specification, performance, production and conformity. European Committee for Standardization, Brussels, Belgium, 2000.

36. EN 934-2:2001 Admixtures for concrete, mortar and grout Part 2: Concrete admixtures - Definitions, and requirements. European Committee for Standardization, Brussels, Belgium, 2001. 
CEMENTO SĄNAUDŲ BETONO MIŠINYJE MAŽINIMAS NAUDOJANT SUPERPLASTIFIKATORIAUS SNF PRIEDĄ

\section{A. Kapelko}

\section{S antrauka}

Nagrinejjamas cemento taupymo betono mišinyje, naudojant natrio druskos formaldehido polikondensato sulfoninès naftaleno rūgšties priedą (SNF), klausimas. Atlikti tyrimai parodè šio priedo dideli plastifikuojanti poveiki, taip pat jo poveiki portlandcemenčio rišimosi trukmès pailgèjimui. Pridejjus $1,5 \%$ priedo, galima gerokai sutaupyti cemento, kartu mažejja ir sunaudojamo vandens kiekis (esant pastoviam V/C santykiui). Tuo pat metu betono tankis, stipris gniuždant, absorbcija ir laidumas vandeniui lieka nepakitę. Superplastifikatoriaus ekonominiam efektyvumui apskaičiuoti siūloma taikyti cemento taupymo indeksą $S_{c}$ ir cemento sunaudojimo betonuose indeksą $I_{e c}$.

Reikšminiai žodžiai: betono mišinys, betono mišinio savybès, superplastifikatorius SNF, betonas, betono fizikinės ir mechaninès savybès, cemento taupymas, indeksai $S_{c}$ ir $I_{e c}$.

Aleksander KAPELKO. Assistant Professor at the Institute of Building Engineering of Wrocław University of Technology, Poland. He gives lectures and laboratory classes in technology of concretes and mortars. Chief of the Division of special and composite materials and a chief of Laboratory of concrete technology accredited by Polish Centre for accreditation. Member of Polish Association of engineers and building technicians (PZITB). His research interests include the technology of composite and special materials with chemical admixtures and additions, as well as the investigations and estimations of of building materials quality. 